\title{
POR UM FREUD MAL SONHADO
}

A câmera desliza defronte do edifício, depois avança em direção à janela. Súbito, recua, a partir da janela, mas já no interior do próprio edifício: a Embaixada da República de Miranda é tomada de assalto. Indiscreta e silenciosa, a câmera perscruta a intimidade da burguesia. A burguesia e seus comparsas ou servidores - a diplomacia, a Igreja, o exército e a polícia. A burguesia e o inimigo politico imediato - um voluntarismo empirista, distante da realidade a operar efetivamente, e entregue à tarefa de eliminação fís.ca de um embaixador. O juízo de valor é a gargalhada. Sob a regência de Buñuel a sátira começa.

Le Charme Discret de la Bourgeoisie volta a nos propor o tema da prática estética enquanto sistema diferencial de transformaçōes operadas sobre uma matéria-prima específica - a prática ideológica (1). Com efeito, Buñuel se apropria de fragmentos de uma certa ideologia burguesa, submete material as leis da sua prática cinematográfica e nos entrega o produto em forma de sátira, mas sobretudo filme (2). E o produto passa a ser, aos olhos da teoria, uma figura exemplar de como a matéria-prima dada se vê parcialmente incorporada às próprias leis de produção do filme, e parcialmente legisla sobre si mesma. Se retomarmos o filme através dos conceitos propostos por Hjelmslev, verificaremos que, a partir de uma certa substância do conteúdo, Buñuel a organiza sob o signo do riso: o satírico preside a organização inicial dessa substância e está dado na "maneira do filme falar do que fala" (3) - o que nos remete ao plano da forma do conteúdo. Mas esta "maneira de falar", que implica a sátira, rege seu discurso a partir de um elemento da matéria falada. O objetivo do nosso texto é isolar a questão desta passagem.

(1) Estamos pensando no conceito de ideologia prática, tal como o entende Althusser: "As ideolog as práticas são formações complexas de montagens de noções-representações-imagens, de um lado, e de montagens de comportamentos-condutas-gestos-atitudes, de outro. O conjunto funciona como normas práticas que governam a atitude e a tomada de oposição concreta dos homens em relação aos objetos reais, de sua existência social e individual, de sua hitória". Cf. "Teses', in Epistemologia, 2, Rio de Janeiro, Tempo Brasileiro, 1973, pp. 126-7.

(2) O interesse do nosso texto questionará parcialmente a organização formal deste produto específico (fílmico) da estética.

(3) METZ, Christian, "O Dizer e o Dito no Cinema: Ocaso de um Verossímel", in A Significação no Cinema, São Paulo, Perspectiva, 1972, p. 232. Metz trata aqui dos conceitos de Hjelmslev utilizados por nós neste estudo. 
Em Le Charme Discret a substância do conteúdo é constituída por certos fragmentos de ideologia: "formações complexas de noções-representações-imagens ou de comportamentos-gestos-condutas-atitudes" são erguidos perante os protagonistas como pontos normativos de referência. Assim, Buñuel submete suas personagens a um comportamento presidido por uma ética de aparência e bom tom. A mesma burguesia capaz de zombarias a Napoleão impõe-se a formalidade de cobrar de um embaixador latino-americano os ideais heróicos da democracia burguesa. E se submete, por outro lado, às regras que ditam a maneira de partir o carneiro, tomar martini ou comer peixe. Os trajes devem convir às suas situações: se não estão submetidos à regra, a exemplo do arcebispo Dufour, as personagens se expõem ao risco de não serem reconhecidas.

Paradoxalmente, entretanto, a burguesia se expōe reiteradamente ao risco. $\mathrm{Na}$ figura da jovem Florence, Buñuel localiza o mais alto grau de problematização das normas: logo de saída, se surpreende uma advertência paternal dirigida a ela por François Thevenot. De fato, seguidamente Florence viola as regras que deveriam governá-la: excede-se no álcool, tira da criada as flores trazidas a Alice Sénéchal na primeira sequência (afinal o jantar não se realizou). Tudo se passa como Florence estivesse aquém das maneiras exigidas: as normas práticas do conjunto já não são suficientes para dirigir a atitude dos agentes da ideologia. Neste sentido, talvez Thevenot apareça como o guardião solitário das regras. Sob seu espanto passivo, todos se precipitam no pecado momentâneo do esquecimento - o casal Sénéchal com insistência. As regras do "receber em casa" são sempre violadas por Alice e Henri: o mal-entendido (?) inicial que as adia para "amanhã", o desejo de posse amorosa no momento em que os convidados esperam, a naturalidade com que servem um jantar quase inexistente

Mas a pressão sobre as regras não parte apenas destes agentes imediatos dos rituais questionados. No momento em que o carneiro é partido como convém ao ritual e as normas de cerimônia estão asseguradas - então a pressão acontece de fora para dentro: o velório no restaurante, a falta de leite, café ou chá, a intervenção da policia ou da guerrilha. A partir destas transgressões de todos os flancos, o próprio ritual que as normas suportam se torna insustentável: tudo se passa como se ele insistisse em existir num mundo que lhe nega o seu lugar Sorrateiramente, a burguesia é posta (e se põe) em causa: descobrese num palco, personagem de uma peça da qual "não sabe o texto". Buñuel não testemunharia aqui uma burguesia incapaz? E, com efeito, esta inca pacidade não estaria reafirmada em todo o filme, expressa sob a metáfora dos banquetes indefinidamente inacabados? (4).

A primeira leitura nos proporia localizar aqui o elemento fundamen,al da substância do conteúdo. De fato, não são os almoços e jantares interrompidos a grande constante de toda a trama? O questionamento da cerimônia pelo questio-

(4) Não se deve esquecer que Buñuel isola uma certa fração de classe no interior da burguesia. Trata-se de uma burguesia alheia ao processo de produção, cuja renda parece sobrevir do tráfico de drogas. 
namento dos comportamentos-condutas-gestos-atitudes (ideológicos) que fundamentam a própria cerimônia não atravessa o filme, do princípio ao fim? Não se põe o expectador sempre à espera do projetado jantar em casa do Coronel, que afinal nunca se realiza, a não ser em sonho?..

Entretanto, Buñuel se apropria de um outro fragmento da ideologia burguesa e procura voltá-lo contra a própria burguesia, por uma integração satírica desse fragmento ao processo narrativo do filme. De simples elemento da substância do conteúdo, o fragmento ideológico acaba se incorporando à própria organização estabelecida pela forma do conteúdo. De fato, em Le Charme Discret de la Bourgeoisie, a burguesia supersticiosa decifra o mundo pela astrologia e pelos sonhos. Recorre a um Freud caricaturado ( filtrado pelo código ideológico de uma revista feminina?) e o levanta em posição às máximas e pensamentos de Mao. Aqui se opera a inversão satírica: já que o mundo é decifrável-pelo Complexo de Édipo (e pelo Euclides), que se decifre a burguesia sob o signo dos seus complexos.

A invocação da infancia por um lugar-tenente da cavalaria e a narração de um sonho por um sargento do exercito nos arremessam de pronto numa dimensão preenchida pelo Complexo de Édipo. Em ambos os relatos o narrador encarna o órfão: investido da figura da mãe, vive ou sonha uma situação.

No primeiro caso, o órfão prestes a entrar para o Colégio Militar é um jovem submisso à figura do pai, désposta e indiferente. Um dia, interrompe uma frase escrita sobre o espelho ("Maman, je...") e é surpreendido pela vista da mãe falecida. No quarto que abriga os objetos da morta, Hubert é incitado ao assassinio do pai, que em realidade não seria seu pai, mas o assassino dele. A missão the é entregue sob circunstâncias que a tornam sagrada: “C'est la derniére chose que ta mére te demande”. Promovida a sublimação, o pai morre envenenado, e no dia seguinte Hubert é recebido no Colégio Militar, "oú une vie passionante m'attendait".

O mesmo tema retoma pela narração do sonho do sargento, atacado igualmente por Édipo. O oficial acaba de chegar a uma rua escura, onde o silêncio é interrompido por um burburinho de vozes e por um sino insistentemente místico. As pessoas que reconhece, todas mortas há algum tempo, habitam este lugar onde se ganha uma estranha palidez e um cheiro de terra. É aqui que o narrador se encontra com uma jovem, a mulher amada, que após muitos desencon'ros viria definitivamente para junto dele. Entretanto, ela volta a escaparlhe e o sonho termina com a brusca revelação de sua identidade: "Oú est-tu, mére, je te cherche parmi les ombres".

Em ambos os relatos, a burguesia é público embevecido e cheio de gratidão. A narração desencadeia em Monsenhor Dufour um princípio de reflexão acerca do regresso de Lázaro; os comensais permanecem concentrados, sèriamente in- 
comodados com o mistério que os sonhos perecem comportar (5). Talvez fosse preciso vincular o Complexo de Édipo à profissão das armas: saltar do mito da Mãe em direção ao mito da Pátria. O que mais importa, entretanto, é o anúncio de uma atmosfera borgeana, possivelmente a grande consequência da inversão satírica de Buñuel. Sem dúvida, a narração do sonho do sargento nos adverte e prepara logo de saida: trata-se realmente da narração de um sonho, embora a lembrança de Lázaro por Dufour levante uma suspeita. Mas a evocação de Hubert propỏe a dúvida que assaltará definitivamente o expectador: o seu relato nos transporta para um mundo em que não é possível um critério que separe o real e o imaginário.

O próprio arcebispo Dufour está precipitado na dialética freudista do processo satírico. O ponto de referência para sua elaboração enquanto personagem é outra vez o triângulo mágico: Pai-Mãe-Filho. O Monsenhor assume estranhamente o ofício de jardineiro em casa de M. e Mme. Sénéchal: sabemos que Dufour o aptendera ainda criança co $\mathrm{m}$ ojardineiro que servira os pais, mortos violentamente por um assassino desconhecido. Buñuel parece esboçar uma metáfora linear - o clero servidor da burguesia - quase reafirmada pouco depois, quando o arcebispo é surpreendido assumindo ocasionalmente as vezes de mordomo. Entretanto, Buñuel vai mais além e reserva ao arcebispo sua (satírica) autonomia enquanto personagem.

Durante seu ofício no Jardim, Monsenhor Dufour é chamado às pressas para um caso de extrema-unção. Novamente o expectador é transportado para uma atmosfera de sonho, sem qualquer advertência (e afinal, daqui a pouco Rafael Acosta despertará). Estendido na cama, o moribundo tem um crime antigo a confessar: o assassinato dos patrões, aos quais servira como jardineiro. Deus acaba de dispor frente a frente o criminoso e o filho dos senhores assassinados. Cumprida a formalidade e concedida a extrema-unção, Dufour faz justiça com as próprias mãos: a vítima assume irônicamente as feições de Jesus crucificado, este Deus "si bon, si doux".

A rede freudista se oferece às especulaçōes psicanalíticas do expectador. Pressentia Dufour quem fosse o assassino (6) e se identificava (profissionalmente) com ele, em função de um ódio reprimido pelos pais? a opção pela batina (partindo de alguém que abdica de uma casa tão grande quanto a dos Sénéchal) não seria o fruto da autapunição pelo ódio proibido, e afinal, o novo e súbito

(5) O ritual destas narrações torna-se algo a que as classes dominantes devem dar prioridade. Com efeito, o sonho do sargento é narrado, apesar de um comunicado enviado do Estado-Maior, ordenando expressa-
mente a mobilização das tropas.

(6) Quando interrogado pela identidade do assassino, o arcebispo afirma desconhecê-la, embora seu semblante assuma uma expressão receosa dé

Não negamos que estas especulações em torno de Dufour pareçam fantasistas e grosseiras: mas não é justamente esse o projeto de Buñuel? 
exercício do super-ego não resolveria provisòriamente o conflito através do ato de vingança?

O que mais importa, entretanto, é a verificação desta narrativa tecida a partir da sucessão de sonhos: Rafael Acosta sonha que Dufour se torna assassino. Buñuel se põe a decifrar a burguesia na atmosfera de suas próprias fantasias: o resultado é que o expectador vai sendo envolvido numa rede de armadilhas. Quando passa a acreditar naquilo que vê, surpreende-se logrado: as situações vividas nos remetem ao sonho. É então que se descobre que a narrativa progride por ciladas. Convidados para o jantar em casa do Coronel, os comensais estão à mesa: súbito, a cortina se abre e a burguesia se descobre num palco, personagem de uma peça da qual "não sabe o texto". Felizmente, no entanto, trata-se apenas de um sonho, M. Sénéchal desperta. Em seguida, agora no jantar que acreditamos real, um novo incidente o interrompe: uma pequena discussão entre o Coronel e Rafael Acosta toma proporções inesperadas e se resolve por uma agressão armada do diplomata. Mas então é a vez de M. Thevenot despertar: e surpreendentemente o exptctador é informado de que Thevenot sonhara que Sénéchal sonhara que o jantar no Coronel acabara vexadamente num palco, mas que em realidade (?) esse jantar fora interrompido pela agressão drástica do Embaixador, na esfera de um outro sonho. O expectador já não se sente apenas incapaz de determinar onde começa o sonho e onde acaba a realidade: para além disso, já năo sabe determinar quem sonha e quem é sonhado. Seguidamente a burguesia sonha e vai trazendo à tona seus desejos e temores mais intimos. Se os sonhos de Sénéchal e Thevenot revelam o medo pelo esquecimento das regras e pela denúncia da representação, as constantes do sonho de Rafael nos remetem diretamente ao traficante de drogas e ao representante politico de um régimé dé opressão. Nesta altura, o expectador se vê muitas vezes apresentado à República de Miranda em pessoa: afinal, na tortura presidida pelo célebre "brigadier sanglant" (fora do mundo do Inspetor apenas um submisso brigadeiro), Buñuel não nos proporia a leitura de um certo "estilo" latino-americano para além das simples aparencias francesas?

Mas o sonho de Acosta convida a uma pergunta que coloca em questão a totalidade do progresso narrativo de Buñuel: afinal de contas, o que realmente sonha o Embaixador? Em outros termos, onde situar a fronteira de príncipio deste sonho? Por volta do almoço interrompido pela chebada do Inspetor Delecluze? arcebispo ao moribundo. É preciso que se faça uma regressão até a sequencia do arcebispo ao moribundo. É preciso que se faça uma regressão até a sequencia imediata ao sonho sonhado por Henri no sonho de Thevenot? Mas é justamente a existencia deste sonho comportado por outro sonho que nos previne sobre a possibilidade de desdobramento. Com efeito, se Sénéchal sonha no sonho de Thevenot e se Delecluze sonha no sonho de Rafael, será que todos os sonhos não estão comportados no interior de um grande sonho, o Refael? Mas os desdobramentos explícitos nos avisam sobre a possibilidade dos desdobramentos ocultos, e não sobre sua existência efetiva. Este vislumbramento do possivel nos arremessa de pronto na impossibilidade de determinar o que não foi sonhado 

O que está comportado na realidade do sonho, e o que não está? Por um lado,
quem sonha? E por outro, quem é sonhado?

De qualquer maneira, a utilização do sonho como astúcia de narração não const tui um processo apenas ocasional, mas informa do principio ao fim a empresa narrativa de Buñuel. Neste sentido, a prática cinematográfica está longe de operar de maneira meramente exterior com a substância do conteúdo proposta, como supuseram muito tempo as estéticas da distinção mecânica entre a forma e conteúdo. A prática ideológica tomada passa a constituir (por um processo satírico de inversão) um dos elementos de organização do próprio filme: arma de dois gumes, a ideologia está voltada contra si mesma. O projeto de Buñuel está próximo em alguma coisa do procedimento satírico de Cervantes no $D$. Quixote: a forma do conteudo organiza a substância do conteúdo a partir de um elemento extraido da própria substâncía do conteúdo. Le Charme de la Bourgeoisie testemunha a tranformação contra a burguesia de um valor incorporado por ela à sua condição de classe - um Freud lido e vivido (sonhado?) a sua maneira. 